\title{
KARST PALEO-COLLAPSES AND THEIR IMPACTS ON MINING AND THE ENVIRONMENT IN NORTHERN CHINA
}

\author{
Gongyu Li \\ Xi'an Research Institute of China Coal Technology \& Engineering Group Corp., Xi'an, Shaanxi 710054, China; \\ ligongyu@msn.com
}

Wanfang Zhou

ERT, Inc., 12710 Buttonwood Lane, Knoxville, TN 37934,_USA; zhou_wanfang@yahoo.com

\begin{abstract}
Karst paleo-collapses are unique collapse structures widely found in the coal measures of northern China. Their geometric dimensions and internal properties indicate that a compound dissolution of carbonate and gypsum rocks may contribute to their formation. When these collapses are permeable to groundwater flow, they hydraulically connect the coal seams and the karst aquifers, which is a pre-requisite for water inrushes during coal mining. Over the last 40 years, water inrushes through these collapses have caused fatalities, economic losses, and degradation in the environment in northern China. Determination of locations and hydrogeological characteristics of the karst paleo-collapses are essential in preventing water inrush incidents through them. Advanced geophysical prospecting, aquifer testing and accompanied dye tracing are effective approaches to investigating these structures.
\end{abstract}

\section{Introduction}

Cover collapses and rock collapses are two basic types of collapse structures (Newton, 1987). Research of historical records shows that most collapses are cover collapses, leading to sinkholes (Beck, 1991), where unconsolidated sediments overlying carbonate bedrock move downward through dissolution openings into a network of dissolved void space or a single large cavity, capable of accommodating the sediments. The cover collapse sinkholes have been extensively studied and well documented due to their recognized sensitivity to human activities and their impacts on engineering works and the environment (Newton, 1987; Beck, 1984; Beck and Wilson, 1987).

The occurrence of bedrock collapses is rare compared with that of cover collapse sinkholes (Newton, 1987). Most of the human-induced rock collapses are related to dam construction in mountainous areas, where water potential differences between recharge and discharge zones are great (Yuan, 1987). Continuous and repeated change in air and water pressure (the hammer effects) in karst conduits are the main factors triggering rock collapses. In southern China, over $20 \%$ of reservoirs built in areas of bare karst failed to retain water due to the rock collapses at their bottoms (Zou, 1994). Rock collapse dolines are rarely seen in the act of collapsing (White, 1988). None of the reported 1,700 sinkholes in Florida, United States has been confirmed as cave roof collapse (Beck, 1991).

However, these sinkholes are newly developed; on a geologic time-scale, cave-roof collapses are widely distributed as well (Sangster, 1988; Li and Zhou, 1989; Vegter and Foster, 1992). Rock collapses developed in the past geological history are referred to as paleocollapse structures or paleo-collapse breccia pipes or columns. Depending on present hydrogeological conditions in areas of paleo-collapses and the internal properties of these structures, they can function as weak geological media for preferential groundwater flow and contaminant transport (Zhou, 1997; Benson and others, 1991). Inactive paleo-collapse structures can be reactivated by human activities such as dam construction, mining underground minerals, pumping groundwater, and development of landfills. They may also be reactivated by natural events such as earthquakes and neo-tectonic activities.

\section{Karst Paleo-Collapses in Northern China}

Geology and climate are two major factors affecting the development of karst features. Usually, there have been several phases of karstification during geological history. In China, for example, the most striking paleo-karst is found in (1) the Caledonian Orogeny unconformity between the Ordovician limestone and middle carboniferous series in northern China; (2) the unconformity between the Lower Permian limestone and the Upper Permian Series in southern China; (3) the pre- 
Jurassic karstification in the Sichuan basin; and (4) the pre-Tertiary buried karst in northern China.

The effects of paleo-karst can be observed in the various karst features of the carbonate aquifers and the yields of oil and gas reservoirs. They can also be seen in the interrelationships between important mineral deposits and karst aquifers which pose difficult problems in mining engineering. Paleo-collapse structures are one of the most important types of paleo-karst features (Zhou, 1997).

Paleo-collapses are widely distributed in northern China, especially in the provinces of Shanxi, Hena, and Hebei, as listed in Table 1 . They have been found in over 50 coalfields and their total number exceeds 3,000 with an intensity of up to 70 collapses $/ \mathrm{km}^{2}$. In some stopes paleocollapse structures comprise $30 \%$ of the total mined areas. They are recognizable in plan view as patches of breccia with miscellaneous lithological composition, generally derived from overlying strata and completely enclosed in lower bedrock. Diameters range from tens to hundreds of meters with the largest measuring $1,050 \mathrm{~m}$. In profile, they take the form of vertical cylinders several hundred meters deep. No bedding is apparent inside these structures and the different rocks are intermixed and poorly sorted. They generally contain higher proportions of displaced blocks and the adjoining strata are offset as a result of dissolution-collapse. Fragments tend to be sharply angular, typically rotated, show little sign of wear and appear to have dropped from their original stratigraphic position. Figure 1 shows some common profiles of paleocollapses reported in northern China. While the majority of the paleo-collapses are buried underground, some are exposed to surface and expressed as depressions.

Usually the infill materials in the paleo-collapse structures are tabular 5-40 cm angular fragments which display random orientation. Sides are subparallel and contacts between host and fills are sharp and irregular. In most cases, the matrix consists of clastic sediments without cement or mineralization. These structures are generally perpendicular to the ground surface. However, they can become inclined as a result of tectonic movements but remain perpendicular to the surrounding strata. Voids may be present at the top of the structures and drill bits can drop noticeably during borehole drilling. Closed depressions sometimes form in the surficial sediments without any apparent fluctuation in water level or any construction works taking place.
Table 1. Paleo-collapses reported in northern China's coalfields.

\begin{tabular}{|c|c|c|c|c|c|c|}
\hline \multirow{2}{*}{ 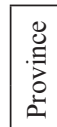 } & \multirow[t]{2}{*}{ Location } & \multirow{2}{*}{$\begin{array}{l}\text { Number } \\
\text { of paleo- } \\
\text { collapses }\end{array}$} & \multicolumn{3}{|c|}{$\begin{array}{l}\text { Max. size of collapses } \\
\text { (m) }\end{array}$} & \multirow{2}{*}{$\begin{array}{l}\text { Water } \\
\text { inrush }\end{array}$} \\
\hline & & & length & width & height & \\
\hline \multirow{5}{*}{ 离 } & $\begin{array}{l}\text { Xishan Mine, } \\
\text { Taiyuan }\end{array}$ & 1300 & 40 & & & \\
\hline & $\begin{array}{l}\text { Yangquan } \\
\text { Mine }\end{array}$ & 960 & 300 & & 600 & \\
\hline & Huoxian Mine & 405 & 60 & & & 2 \\
\hline & \begin{tabular}{|l} 
Zhuangjia \\
zhuang Mine, \\
Fenxi
\end{tabular} & 360 & 30 & & & 1 \\
\hline & Shenlin Mine & 75 & 30 & & & \\
\hline \multirow[b]{6}{*}{$\begin{array}{l}\overline{8} \\
\overline{0} \\
\overline{1}\end{array}$} & Jingxing Mine & 112 & 300 & 23 & 300 & 1 \\
\hline & $\begin{array}{l}\text { Fenfeng Mine } \\
\text { No. } 1\end{array}$ & 6 & 200 & 40 & & \\
\hline & \begin{tabular}{|l|} 
Fengfeng \\
Mine no. 4
\end{tabular} & 20 & 73 & 150 & & \\
\hline & $\begin{array}{l}\text { Yangquhe } \\
\text { Mine }\end{array}$ & 6 & 204 & 57 & & \\
\hline & $\begin{array}{l}\text { Fangezhuang } \\
\text { Mine, Kailuan }\end{array}$ & 9 & 95 & 74 & 280 & 4 \\
\hline & \begin{tabular}{|l} 
Tangjia \\
zhuang Mine, \\
Kailuan
\end{tabular} & 5 & 116 & & 50 & \\
\hline \multirow[b]{3}{*}{ 壳 } & Hebi Mine & 22 & 200 & 60 & 398 & \\
\hline & \begin{tabular}{|l} 
Tongyie \\
Mine, Anyang
\end{tabular} & 22 & & & & 1 \\
\hline & $\begin{array}{l}\text { Lifeng Mine, } \\
\text { Jiaozuo }\end{array}$ & 1 & & & & 1 \\
\hline \multirow{12}{*}{ 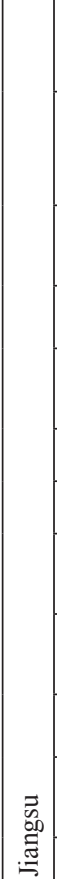 } & $\begin{array}{l}\text { Dahuangsha } \\
\text { Shaft, Xuzhou }\end{array}$ & 17 & 200 & 146 & & 1 \\
\hline & \begin{tabular}{|l} 
Qingshan \\
zong Shaft \\
No. 1
\end{tabular} & 1 & & & & 1 \\
\hline & $\begin{array}{l}\text { Qingzhuan } \\
\text { Mine }\end{array}$ & 1 & 38 & 19 & & \\
\hline & Liuxing Mine & 1 & & 20 & & \\
\hline & $\begin{array}{l}\text { Jincheng } \\
\text { Mine }\end{array}$ & 27 & 125 & 62 & & \\
\hline & Xinhe Mine & 3 & 136 & 100 & & \\
\hline & Jiahe Mine & 1 & 135 & 100 & & 1 \\
\hline & $\begin{array}{l}\text { Wangzhuang } \\
\text { Mine }\end{array}$ & 1 & 122 & 93 & & \\
\hline & $\begin{array}{l}\text { Quanzhao } \\
\text { Mine }\end{array}$ & 7 & 60 & 40 & & \\
\hline & Hanqiao Mine & 4 & 170 & 100 & & \\
\hline & $\begin{array}{l}\text { Dongzhuang } \\
\text { Mine }\end{array}$ & 1 & 280 & 200 & & \\
\hline & Yian Mine & 1 & & & & \\
\hline
\end{tabular}




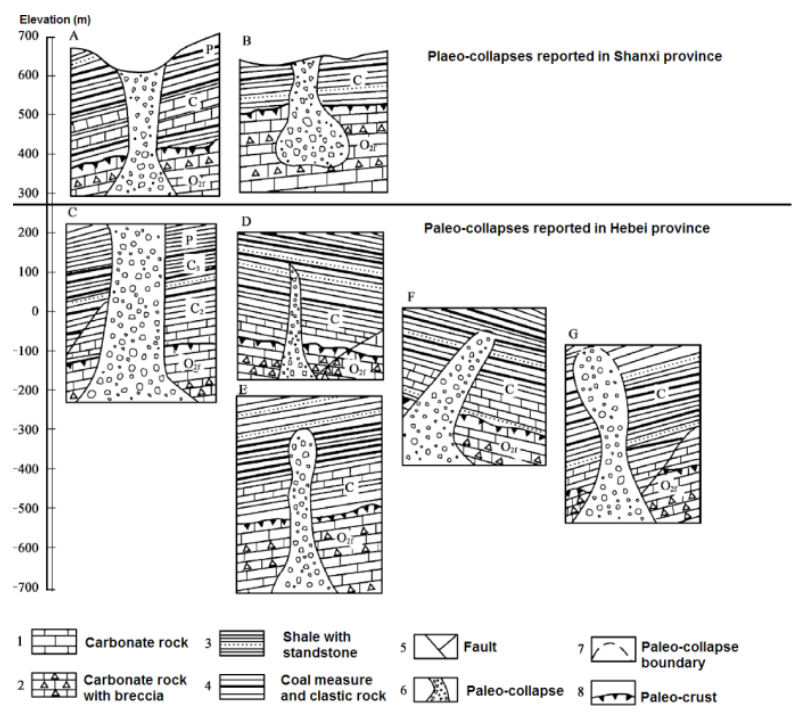

Figure 1. Select paleo-collapse profiles reported in northern China (modified from LU and Zhang, 2008). Elevation in meters is shown on the left side of the figure.

The paleo-collapses found in northern China are of different hydrogeological types depending primarily upon the lithology of their internal rock blocks, extents of weathering and cementation, and the secondary structures associated with the collapses. Based on the exposed paleo-collapses from drillings and excavations, the paleo-collapses can be permeable, impermeable and poorly permeable. In different paleo-collapses or different locations of the same paleo-collapse, the rock blocks may have different hydrogeological properties. The permeable paleo-collapses consist of weathered rock blocks but they are typically unconsolidated and not cemented. The impermeable paleo-collapses consist of weathered rock blocks that are cemented by weathered shale and mudstone. The poorly permeable paleocollapses consist of partially cemented rock blocks with secondary fractures around the border of the collapses. Table 2 summarizes the hydrogeological properties of some of the paleo-collapses.

Figure 2 shows profiles of the three types of paleocollapses. All of the three paleo-collapses are exposed in the Fangezhuang mine. Paleo-collapse No. 9 is permeable; paleo-collapse No. 2 is impermeable; and paleo-collapse No. 1 poorly permeable.

\section{Formation Mechanisms of Paleo-Collapses}

The origin of this type of collapse is not fully understood, but the bottom of a paleo-collapse structure is usually
Table 2. Summary of hydrogeological properties of paleo-collapses reported in northern China.

\begin{tabular}{|l|l|l|l|}
\hline $\begin{array}{l}\text { Coalfield, } \\
\text { Province }\end{array}$ & $\begin{array}{l}\text { Number of } \\
\text { reported } \\
\text { paleo- } \\
\text { collapses }\end{array}$ & $\begin{array}{l}\text { Number of } \\
\text { impermeable } \\
\text { paleo- } \\
\text { collapses }\end{array}$ & $\begin{array}{l}\text { Percent of } \\
\text { impermeable } \\
\text { paleo- } \\
\text { collapses }\end{array}$ \\
\hline $\begin{array}{l}\text { Yangquan, } \\
\text { Shanxi }\end{array}$ & 450 & 450 & 100 \\
\hline $\begin{array}{l}\text { Xishan, } \\
\text { Shanxi }\end{array}$ & 1,300 & 400 & 30.8 \\
\hline $\begin{array}{l}\text { Fengfeng, } \\
\text { Hebei }\end{array}$ & 65 & 30 & 42.6 \\
\hline $\begin{array}{l}\text { Jingxing, } \\
\text { Hebei }\end{array}$ & 120 & 80 & 66.7 \\
\hline $\begin{array}{l}\text { Fengezhuang, } \\
\text { Kailuan, Hebei }\end{array}$ & 13 & 3 & 23 \\
\hline $\begin{array}{l}\text { Tangjiazhuang, } \\
\text { Kailuan, Hebei }\end{array}$ & 6 & 6 & 100 \\
\hline $\begin{array}{l}\text { Xinwen, } \\
\text { Shandong }\end{array}$ & 14 & 7 & 50 \\
\hline $\begin{array}{l}\text { Feicheng, } \\
\text { Shandong }\end{array}$ & 10 & 9 & 100 \\
\hline $\begin{array}{l}\text { Tengxian, } \\
\text { Shandong }\end{array}$ & 5 & 2 & 90 \\
\hline $\begin{array}{l}\text { Yanzhou, } \\
\text { Shandong }\end{array}$ & 2 & permeable & 20 \\
\hline
\end{tabular}

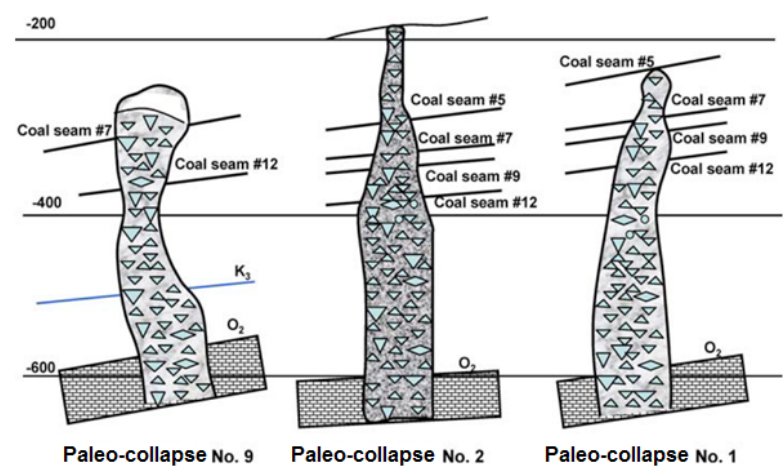

Figure 2. Longitudinal cross sections of paleocollapses No. 9 (highly permeable), No. 2 (impermeable) and No. 1 (poorly permeable) in Fangezhuang Coal Mine (modified from Yin and Zhang, 2005). Elevation in meters is shown on the left side of the figure.

in the underlying karstified Ordovician limestone, and the lithological character of the breccia gives a strong impression of collapse of upper strata. Gypsum in the Ordovician limestone is recognized as playing an important role in paleo-collapse formation ( $\mathrm{Li}$ and Zhou, 1990). Sulfate-reducing bacteria (SRBs) may help initiate and accelerate the dissolution process of the 
carbonate rocks. Figure 3 presents a schematic diagram depicting the compound dissolution process in which the limestone is dissolved by both carbonic acid and sulfuric acid. In additional to presence of natural acid-producing gases, gypsum can produce $\mathrm{H}_{2} \mathrm{~S}$ by $\mathrm{SRBs}$ and additional $\mathrm{CO}_{2}$ by interacting with carbonate rocks.

In Shanxi province gypsum is present in the Middle Ordovician Fengfeng Formation. It contains up to $60 \%$ of secondary gypsum, present as thick massive beds, nodular gypsum and gypsum interbedded with mudstone and dolomite. The formation rests on the Majiagou Formation which also contains some gypsum and is the major regional aquifer. In the Tiejingou deposit near Yangquan the Fengfeng Formation ranges in thickness from several tens to more than one hundred meters. Within the formation large palaeokarst caves, situated in the present vadose zone, have collapsed and are filled with breccia. However, karst fissures are still undergoing dissolution and enlargement. The active dissolution of gypsum, indicated by sulphate-rich springs, confirms that the gypsum karst is still evolving.

Shanxi province is in a semi-arid environment undergoing uplift. Palaeokarst, such as that originally developed under phreatic conditions in the Ordovician Fengfeng Formation, has been uplifted above the water table and preserved. In the Fengfeng Formation the dissolution of the gypsum has caused the formation of extensive breccia beds with associated breccia pipes or collapse columns that have propagated upwards through the active coalfields ( $\mathrm{Li}$ and Zhou, 2006). Preservation of gypsum karst is likely when climatic conditions change causing a reduction in the availability of water to the natural systems. In this way the gypsum karst of southwest Oklahoma (Johnson, 1990) was preserved. Pollen/spore samples from underground deposits have

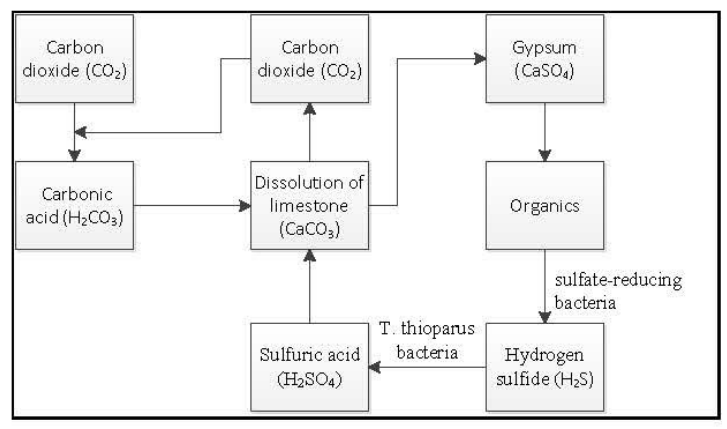

Figure 3. Schematic diagram of compound dissolution of limestone and gypsum. yielded a temperate, but dry forest/grassland assemblage when the collapses occurred (Lu and Copper, 1997).

In active karstification situations gypsum can dissolve very rapidly and caves can quickly enlarge, or amalgamate, become unstable and collapse. When this occurs collapse columns or breccia pipes can propagate upwards and cause surface collapse. The sizes of the breccia pipes and collapses relates directly to the thickness and strength of the gypsum deposits. The more massive, thick and homogeneous the deposit, the larger are the caves that can be supported and consequently the larger the collapses and breccia pipes. When the gypsum between the collapse columns also dissolves the whole sequence effectively founders onto an irregular bed of breccia.

The nature of the underlying and overlying strata adjacent to the gypsum also has a profound influence on the way gypsum karst develops. In sequences where the adjacent rocks are largely impervious the karst can only develop along the joints in the gypsum. In phreatic situations, where the gypsum is underlain, or overlain, by porous dolomites or sandstones, water enters the gypsum in a diffuse way. When this happens dissolution progresses on many fronts and maze cave systems can develop, such as those observed in the Ukraine (Andrajchouk and Klimchouk, 1993). In this situation much of the dissolution occurs at the contacts with the adjacent strata which may also be karstified. In the maze caves the passages range from joint-controlled networks of small stable caves with little dissolution, to networks of actively dissolving conduits with large and unstable cavities; these commonly have subsidence associated with them.

Where thin beds of gypsum are interbedded with porous beds of limestone or dolomite (or sandstone), the potential for the hydration of anhydrite and the dissolution of the resultant gypsum is large. When anhydrite hydrates to gypsum, the expansion can cause brecciation of the mineral, brecciation of the adjacent rock, and injection of fibrous gypsum veins; such deposits are present in the Ordovician Fengfeng Formation. When dissolution of the gypsum occurs, cavities result followed by collapse and the formation of layered breccia deposits. Because dissolution is not uniform throughout the deposits, caves can also develop allowing further erosion of the collapsed material. Breccia pipes or collapse columns 
can develop in this type of strata, but may be of smaller dimensions than those developed in the more massive gypsum rocks. This is due to the presence of numerous discontinuities in the bedded sequence and the piecemeal failure of the thin-bedded rock, which will span smaller distances. Where the sequence comprises interbedded gypsum and insoluble, or less soluble, rocks a breccia, largely composed of the insoluble components, can develop along the level of the former gypsum beds. This is the situation that formed breccias at numerous levels, and collapse columns of breccia penetrating much of the sequence, in the Fengfeng Formation of Shanxi Province.

Where gypsum is in contact with adjacent carbonate rocks, the water chemistry associated with the dissolution phenomenon is different to that for gypsum alone, or for limestone alone. The presence of gypsum together with carbonate rocks will usually cause a compound karstification effect. Waters rich in calcium carbonate can aggressively dissolve gypsum and simultaneously deposit calcite (Wigley, 1973). When this occurs the breccias caused by the dissolution of the gypsum may be cemented. Carbonate-cemented breccias, possibly formed by this mechanism, occur in the Fengfeng Formation. Gypsum dissolves easily in flowing water and increases the amount of sulphate in the water. However, the solubility of gypsum in calcium carbonate-rich waters may be decreased by the common ion effect. Conversely, the presence of sodium, magnesium and chloride ions (possibly derived from interbedded dolomites and halite beds) can enhance the dissolution of gypsum. Experimental work shows that the presence of sulphate in the water increases the dissolution rate for dolomite. For water with an $\mathrm{SO}_{4}^{2-}$ content of $1 \mathrm{mg} / 1$ the dissolution amount for dolomite was $1.67 \mathrm{mg} / \mathrm{l}$ while that for limestone was only $0.94 \mathrm{mg} / \mathrm{l}$ (Lu and Cooper, 1997). The result of this groundwater chemistry on karstification is that very intense and pervasive leaching of the carbonate deposits, especially dolomites, can occur resulting in a honeycomb structure of very little strength. The dissolution of the gypsum, when it is complete, can leave just an insoluble residue, commonly of silt or clay.

After the gypsum dissolved and was removed by groundwater, numerous cavities or fractures were left behind. Solution of the gypsum layers and continuous dissolution of the limestone eventually led to the collapse of the overlying strata. Development of a paleo-collapse is envisaged as a more or less continuous process which progresses upward from an initial conduit (cave) until an equilibrium pressure arch configuration is attained. This occurs when a collapse reaches a lithologic unit of sufficient strength, or the cavity is completely filled with breccia and thus becomes self-supporting.

\section{Impacts of Paleo-Collapses on Mining and the Environment}

The absence of coal seams and the sudden inrush of karst water from the Ordovician limestone have been encountered in the mines of the Permo-Carboniferous coalfields of northern China. These events are due to the presence of paleo-collapse structures. Table 2 lists 15 water inrushes reported from the mines, including the largest inrush in the world, which occurred in Fangezhuang Mine in 1984. Karst water gushed into the mine at a flow rate of $34 \mathrm{~m}^{3} / \mathrm{s}$ at a depth of 313 $\mathrm{m}$ below sea level (bsl). The surface level is $27 \mathrm{~m}$ above sea level (asl). The whole mine was flooded within $21 \mathrm{~h}$ and as a result, the regional water table in the Ordovician limestone dropped from $5.94 \mathrm{~m}$ asl to $111.09 \mathrm{~m}$ bsl. The cone of water depression covered $84 \mathrm{~km}^{2}$ with a north-south axis of $25 \mathrm{~km}$. The fall in the level of the water table in the Ordovician limestone caused serious problems for local residents. These included the drying up of their water supply wells, contamination of the groundwater and the formation of new sinkholes. The water inrush led to the development of 17 cover collapses, with resulting sinkholes ranging in diameter from 2.5 to $3 \mathrm{~m}$ and with depths of 3 to $12 \mathrm{~m}$.

Three basic conditions are required to cause a water inrush. These are the presence of:

- water-bearing karst conduits or a nearby water body;

- water-permeable internal structures in the paleocollapses; and

- water pressure differences between the karst aquifer and the working area.

The relative location of a mine to the active flow zone or karst conduits in karst aquifers determines the amount of water that can flow into the mine. In the presence of a large water-pressure difference, hydrofracturing will facilitate the upward flow of Ordovician karst 
water into mines. Apparently inactive paleo-collapse structures or those which have been cemented can be reactivated by activities such as mining, pumping water, dam construction, and landfill development. They may also be triggered by natural events such as neotectonic movements and earthquakes. Table 3 provides some examples and Figure 4 shows three scenarios where paleo-collapse structures can lead to water inrushes. Mining drifts do not have to intercept paleo-collapse structures directly to cause a geohazards but may instead intercept faults or fractures connected to them. However, once a water inrush occurs and significant water flows into the workings, the whole mine or quarry may become flooded. In cases where different aquifers, several hundred meters apart, become hydraulically connected, the impacts on safety, economy and the environment can be alarming.

\section{Detection and Remediation of Hazardous Paleo-Collapses}

Because the impacts of paleo-collapse structures on the environment and engineering works are serious, it is essential to locate their positions before they are actually exposed. A variety of methods, including geophysical and geochemical ones, are used; exactly which depends on site conditions. In northern China, a combination of pumping tests and dye-tracing tests proved effective in locating two paleo-collapse structures in Fengfeng Mine No.4. The major geological strata in Fengfeng Mine No.4 are shown in Figure 5.

The Carboniferous thin-bedded limestone (Daqing limestone) and the Ordovician limestone are the two major aquifers. The average thickness of the Daqing aquifer is some $5.5 \mathrm{~m}$. Sixty-nine percent of the boreholes sunk in this aquifer, within the mining area, discharge over 0.017

Table 3. Case histories of water inrushes through paleo-collapses in northern China.

\begin{tabular}{|c|c|c|c|c|}
\hline Mine & Date & $\begin{array}{l}\text { Flow } \\
\text { rate } \\
\left(\mathrm{m}^{3} / \mathrm{s}\right)\end{array}$ & Description & Hazard \\
\hline Tongyie Mine, Anyuang & 1965 & 0.39 & $\begin{array}{l}\text { A water inspection borehole drilled into a paleo-collapse } \\
\text { structure from a drift. The initial water flow rate was } 0.5 \mathrm{~m} 3 \\
\text { min- } 1 \text { and water flow rate increased to } 23.3 \mathrm{~m} 3 \mathrm{~min}-1 \text {. An } \\
\text { exploration borehole revealed } 17 \text { cavities within } 50 \mathrm{~m} \text { of the } \\
\text { collapse with the maximum bit-drop of } 2.59 \mathrm{~m} \text {. }\end{array}$ & $\begin{array}{l}\text { The whole mine } \\
\text { was flooded }\end{array}$ \\
\hline Lifeng Mine, Jiaozuo & 1967 & 2 & $\begin{array}{l}\text { Karst developed very well in the area. Intensive mine water } \\
\text { drainage reactivated the paleo-collapse structure. }\end{array}$ & $\begin{array}{l}\text { A working stope } \\
\text { was flooded }\end{array}$ \\
\hline Fagezhuang Mine, Kailuan & 1978 & 1 & $\begin{array}{l}\text { Water flowed into the mine from the sandstone, which is } \\
160 \mathrm{~m} \text { above the underlying Ordovician limestone. A sluice } \\
\text { gate was constructed to isolate the water inflow area and a } \\
0.2 \text {-m fracture was revealed, connected with a paleo-collapse } \\
\text { structure. }\end{array}$ & $\begin{array}{l}\text { Part of a drift and } \\
\text { a working stope } \\
(70,188 \mathrm{~m} 3) \text { was } \\
\text { flooded }\end{array}$ \\
\hline Fagezhuang Mine, Kailuan & 1983 & 0.23 & $\begin{array}{l}\text { A small fault with displacement of } 0.2-0.5 \mathrm{~m} \text { was intercepted } \\
\text { by a working stope. Karst water flowed through a paleo- } \\
\text { collapse structure into the fault and then to the working stope. }\end{array}$ & $\begin{array}{l}\text { The working stope } \\
\text { was flooded }\end{array}$ \\
\hline Fagezhuang Mine, Kailuan & 1984 & 34 & $\begin{array}{l}\text { This is the biggest water inflow incident in the world. The } \\
\text { mining coal seam was } 180 \mathrm{~m} \text { above the Ordovician limestone } \\
\text { but they are connected by a paleo-collapse structure. The } \\
\text { reactivation of the paleo-collapse may be associated with a } \\
\text { recent earthquake in this area. Grouting boreholes revealed } \\
\text { that the top of the sinkhole was unfilled with sediments. Due } \\
\text { to the water inrush, } 17 \text { cover sinkholes were induced on the } \\
\text { surface. }\end{array}$ & $\begin{array}{l}\text { The whole mine } \\
\text { was flooded } \\
\text { and the adjacent } \\
\text { three mines were } \\
\text { threatened }\end{array}$ \\
\hline Huoxian Mine & 1967 & 0.13 & $\begin{array}{l}\text { Karst water flowed into an excavating drift through a paleo- } \\
\text { collapse structure and a connecting fault. }\end{array}$ & $\begin{array}{l}\text { The drift was } \\
\text { abandoned }\end{array}$ \\
\hline Huaxian Mine & 1984 & 0.06 & $\begin{array}{l}\text { Karst water from a paleo-collapse structure flowed into } \\
\text { surrounding fractures and then into the horizontal drift in the } \\
\text { Ordovician limestone. }\end{array}$ & $\begin{array}{l}\text { The drift was } \\
\text { abandoned }\end{array}$ \\
\hline Wucun, Huixian & 1999 & 0.67 & $\begin{array}{l}\text { Karst water from a paleo-collapse structure flowed into the } \\
\text { mining area. }\end{array}$ & $\begin{array}{l}\text { The panel was } \\
\text { flooded }\end{array}$ \\
\hline Dongpang, Xingtai & 2003 & 19.5 & $\begin{array}{l}\text { Karst water from a paleo-collapse structure flowed into the } \\
\text { mining area. }\end{array}$ & $\begin{array}{l}\text { The mine was } \\
\text { flooded }\end{array}$ \\
\hline
\end{tabular}



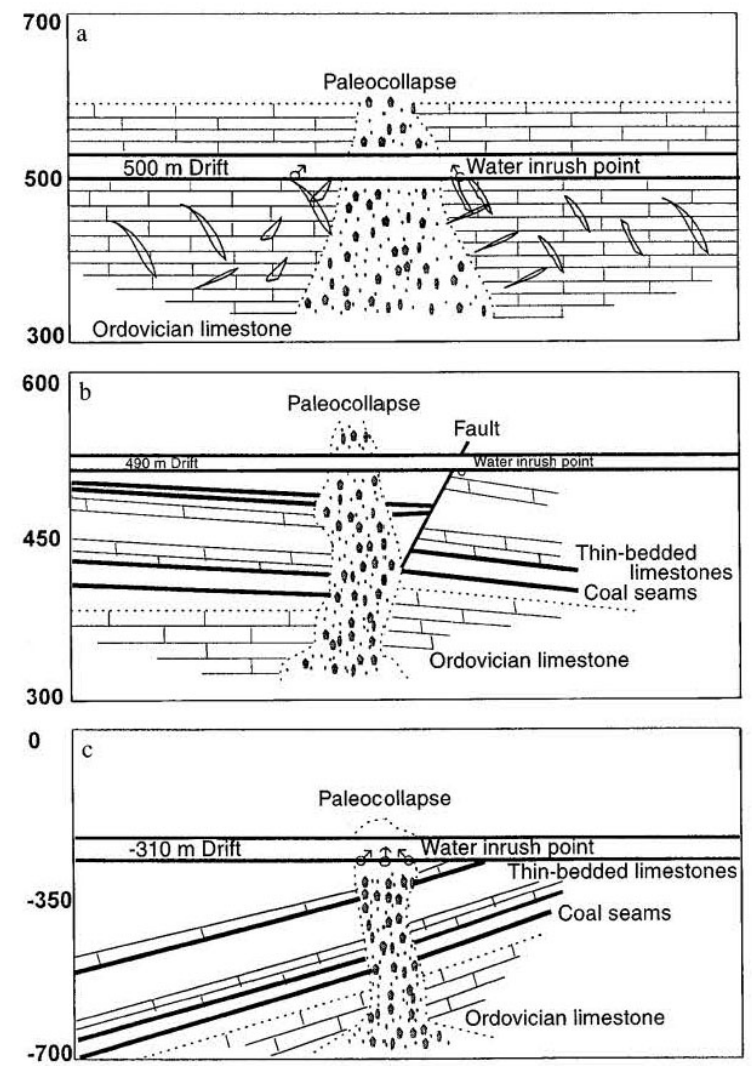

Figure 4a-c. Scenarios where karst water from Ordovician limestone flows into workings through paleo-collapse structures.

a Through paleo-collapse-connected fissures; b through paleo-collapse-connected faults; c through paleo-collapses (Zhou, 1997).

$\mathrm{m}^{3} / \mathrm{s}$ with the maximum discharge of $0.25 \mathrm{~m}^{3} / \mathrm{s}$. Forty days' continuous pumping at $0.68 \mathrm{~m}^{3} / \mathrm{s}$ did not drain the aquifer; instead, its piezometric pressure remained stable. Observation wells in the Ordovician limestone recorded a drop in piezometric level. Therefore, it was concluded that the Daqing aquifer was receiving water from the Ordovician limestone aquifer and subsequent analyses indicated both aquifers to have the same chemistry. Geologic structure analysis and exploratory drilling suggested that lateral inflow from out-side the mine was impossible due to impervious faults (Figure 5). Thus, the connecting link between the two aquifers must be vertical. Paleo-collapse structures are one possible explanation for this, and indeed over twenty such structures have been intersected in the mined area. Surface geophysical methods were unsuccessful in locating the paleo-collapse structures due to the big depths involved (Li and Zhou, 1990). However, the well logs indicated that boreholes at positions A and B in Figure 5 strongly



Figure 5. Locating paleo-collapse structures by dye tracing in Fengfeng Mine No.4 (Zhou, 1997).

adsorbed electric-magnetic waves. Pumping test results together with dye tracing confirmed the findings by the well-logs and enabled the paleo-collapse structures to be located. Four pumping tests were conducted in the Daqing aquifer at the rates of $0.2,0.42,0.33$, and 0.44 $\mathrm{m}^{3} / \mathrm{s}$, respectively. Piezometric pressures in both aquifers showed corresponding fluctuations. The pumping in the Daqing aquifer caused a cone of depression in the Ordovician limestone. During each pumping test, a conservative fluorescent dye was introduced into a borehole in the Ordovician limestone and was collected at all accessible boreholes and discharge points in the Daqing aquifer. The results of the dye tracing are shown in Figure 5. In all cases, the dye first appeared in boreholes in areas A and B. The straight-line velocities were calculated based on the distances and the dye travel times. Dye traces 1, 2, 3, and 4 had velocities to area A of $0.62,0.43,0.08$, and $6.5 \mathrm{~m} / \mathrm{min}$, respectively; and to area B of $0.007,0.0087,0.0017$, and $0.19 \mathrm{~m} / \mathrm{s}$, respectively. The high but contrasting velocities from different traces high- light the rapid flow and strong heterogeneity in the Ordovician limestone aquifer. This in turn assisted in delineation of the possible locations of water-conducting paleo-collapse structures. Subsequently, 16 grouted boreholes were drilled into the suspected paleo-collapse structures and the adjoining Daqing aquifer so as to seal-off and plug the vertical passageways (Figure 6). As a result, the amount of water flowing into the mine decreased from 41 to $3 \mathrm{~m}^{3} / \mathrm{min}$, and the piezometric pressure in the Daqing aquifer dropped significantly, 
as shown in Figure 6. The investment into the grouting operation was recovered from the savings in dewatering cost within 8 months.

\section{Conclusions}

Paleo-collapse structures are common karst features when viewed on a geologic time-scale. They can act as passage- way for groundwater flow and contaminant transport. In northern China, significant damage has been caused in mines as a result of these structures, including the largest water inrush in mining history. Three factors determine whether a paleo-collapse structure will become a water passageway and thus a geohazard:

- The paleo-collapse structure intercepts waterbearing strata;

- The water table in the water-bearing strata is higher than the bottom of the mine working;

- The internal structure of the paleo-collapse favors water flow.

The presence of paleo-collapse structures indicates a strong groundwater flow (conduit flow) in the areas in the past and does not necessarily reflect present hydrogeological conditions. Only those paleo-collapse structures that are within present conduit flow zones or in the vicinity of a water body have the potential to cause geohazards. Paleo-collapse structures may be reactivated by human activities such as dam construction, landfill

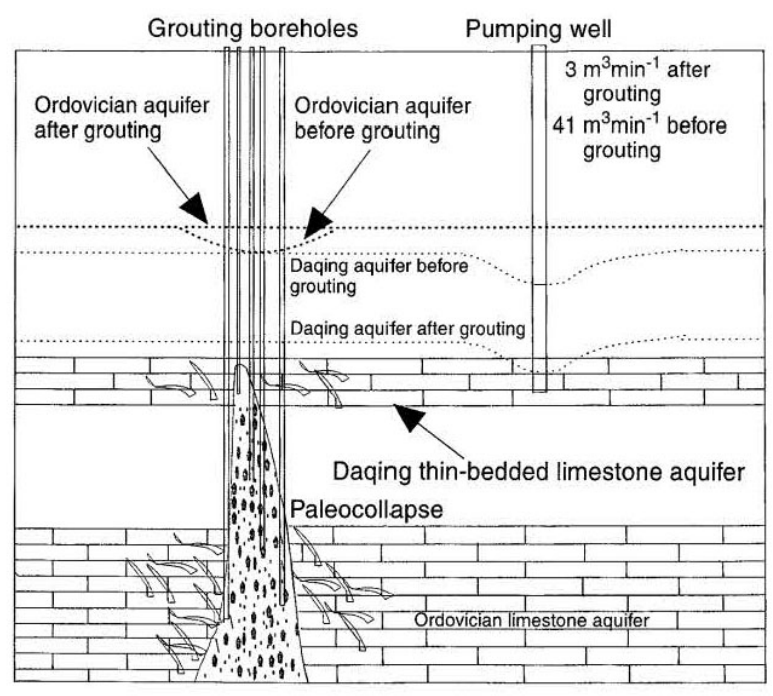

Figure 6. Plugging the paleo-collapse by grouting to prevent water inrush in Fengfeng Mine No.4 (Zhou, 1997). development, mining and quarrying, intensive water pumping, as well as natural events such as earthquakes or neo-tectonic movements. A multidisciplinary approach including geo- physical prospecting, geochemical analyses, test drilling, pumping tests, and dye tracing is required to locate these structures. Grouting is the most effective and perhaps the only possible way of preventing paleo-collapse structures from becoming geohazards. Since grouting is expensive, a cost benefit analysis should be undertaken beforehand.

\section{References}

Andrajchouk V, Klimchouk A. 1993. Environmental change and human impact on karst in the Western Ukraine. Catena Supplement 25: 147-160

Beck BF (editor). 1984. Sinkholes: their geology, engineering, and environmental impact. A.A. Balkema, Rotterdam.

Beck BF. 1991 On calculating the risk of sinkhole collapse. In: Kasning EH (editor). Appalachian karst. Nat. Speleological Soc., Huntsville, AL, pp 231-236.

Beck BF, Wilson WL (editors). 1987. Karst hydrogeology: engineering and environmental applications. A.A. Balkema, Rotterdam.

Benson R, Yuhr L, Hatheway AL. 1991. Groundwater monitoring in unsaturated and saturated zones at a site with paleo-collapse structure. Proc. third conf hydrogeology, ecology, monitoring, and management of ground water in karst terranes. Nashville, TN, pp 131-144.

Li GY, Zhou WF. 2006. Impact of karst water on coal mining in North China. Environ Geol 49: 449-457.

Li JK, Zhou WF. 1989. Geohydrogeological environment for and prediction of water outburst through collapse-columns in coalfields of north China. Carsolog Sin 8: 192-199

Li JK, Zhou WF. 1990. Studies on the control and management of karst water from Ordovician limestone in Collieries, North China. Shaanxi People's Publishing House, Xian.

Lu YR, Cooper AH. 1997. Gypsum karst geohazards in China. In: Beck FB, Stephenson JB (editors): The Engineering Geology and Hydrogeology of Karst Terranes. Proceedings of the Sixth Multidisciplinary Conference on Sinkholes and the Engineering and Environmental Impacts of Karst Springfield/Missouri/6-9 April 1997. A.A.Balkema, Rotterdam.

Lu YR, Zheng F. 2008. Research on development mechanism of sulphate-carbonate rocks' compound karst and engineering impacts. Engineering Sciences of China 10 (4): 4-10 
Newton JG. 1987. Development of sinkholes resulting from man's activities in the eastern United States. US Geological Survey Circular 968.

Sangster DF. 1988. Breccia-hosted lead-zinc deposits in carbonate rocks. In: James NP, Choquette PW (editors), Paleokarst. Springer, Berlin Heidelberg New York, pp 102-116.

Vegter JR, Foster MBJ. 1992. The hydrogeology of dolomitic formations in the southern and western Transvaal. In: Back W, Herman JS, Paloc H (editors) Hydrogeology of selected karst regions. International Contributions to Hydrogeology. 13: 355-376. Heinz Heise, Hannover.

Waltham AC. 1989. Ground subsidence. Blackie \& Son, London.

White WB. 1988. Geomorphology and hydrology of karst terrains. Oxford University Press, Oxford.

Wigley TLM. 1973. Chemical evolution of the system Calcite-Gypsum-Water. Canadian Journal of Earth Sciences 10: 306-315

Yin SX, Zhang JC. 2005. Impacts of karst paleosinkholes on mining and environment in Northern China. Environ Geol 48:1077-1083

Yuan DX. 1987. Environmental and engineering problems of karst geology in China. In: Beck BF, Wilson WL (editors), Karst hydrogeology: engineering and environmental applications. A.A. Balkema, Rotterdam, pp 1-11.

Zhou WF. 1997. Paleocollapse structure as a passageway for groundwater flow and contaminant transport. Environmental Geology 32 (4): 251-257.

Zou CJ. 1994. Hydraulic and hydroelectric karst engineering geology. Hydraulic and Hydroelectric Publishing House, Beijing. 
